\title{
はり降伏型鋼構造骨組の塑性設計用 ベースシャー係数に関する研究
}
正会員 井
上
朗*
正会員 永
田匡
宏**

\section{$\S 1$. 序}

激震時に建物が相当大きな塑性変形を受けることは周 知の事実であり，激震外乱に対する建物の塑性変形応答

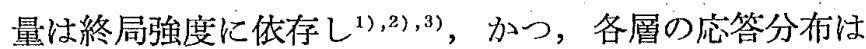
主として終局強度の高さ方向分布に依存する ${ }^{21,3)}$ と指摘 されている。鋼嚅造骨組では，種々の制約条件の下で塑 性設計が可能であるが4，上述の観点がら，鋼構造骨組 の静的耐震設計においては，終局強度に基の゙く塑性設計 法を用いるのが合理的であろう。また，激震による骨組 一の入力エネルギーは，その大部分が骨組構成部材の塑 性変形によって吸収されるから，一部の層の崩壊が骨組 全体の崩壊につながらない上らな設計，例えば，はり降 伏型の設計が望ましいと考えられる。

塑性設計用地震借重は，構造物全体としての終局強度 を規定する終局ベースシヤー係数と終局強度の高さ方向 分布を与学終局層せ几断力分布係数によって表現され る。本研究では, 棚橋 ${ }^{5}$, Housner ${ }^{6), 7)}$ らによって示さ れた耐震設計の基礎概念, 即ち, 地震時の外部仕事と内 部仕事とのエネルギーバランス関倸に基づき，塑性設計 を前提とする鋼構造骨組の静的な耐震設計過程において 設定すべき地震荷重を検討する。対象とする骨組を，は りと筋違のみが塑性化し，いわゆるはり降伏型層崩壊機 構を構成する骨組に絞り，設計用地震荷重に及ぼす骨組 形状, 重短及び笳違の水平力分担率など種々の設計変数 の影響について考察する。更に，本論で求めた地震何重 に対子る塑性設計骨組の弾塑性応答解析結果加ら, 地震 荷重を求めるに際して用いた仮定事項, 及びそれから得 られた結論などに対する数值奏験的検討を行っている。

\section{§2. 基本仮定及び本論の概要}

本論では, 塑性設計骨組の設計用地震荷重を求めるに あたって，次の基本仮定を用いる。

(i ) 地震入力エネルギー $E^{F}$ を下式で与える。

$$
E^{F}=\frac{W_{T}}{2 g} S_{V}{ }^{2}
$$

†本論の一部は昭和 54 年度日本建築学会大会学術講演梗概集 に拉いて発表

* 大阪大学 助手 ** 大阪大学 大学院生 （略和 55 年 1 月 30 日本稿受理・討論期限昭和 56 年 10 月末日）
ここで, $W_{T}$ : 建物総重量, $g:$ 重力加速度, $S_{V}$ : 速度 応答スペクトルである。

（ii）骨組全体の吸収エネルギーは, 設計用地震荷重 を比例荷重とする一方向地震力に対する内部仕事として 表される。

仮定（i）は地震の破壊力皇量化したものである。 (1) 式忙 Housner によって定義され，弾塑性系に対し ても安全側に適用できると仮定されている。Housner 注 この根拠について明確には説明していないが, 次の理由 によるものと考えられる。即ち, 弾塑性振動は, 系が塑 性履歷を受ける場合, 固有周期が変化し, 且つ, 見かけ の減衰定数が増大する線型系の振動問題化置換される ${ }^{3)}$ 。 一方, 速度応答スペクトル $S_{V}$ は, 短周期域を除いて周

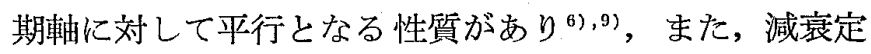
数の増大に伴って $S_{V}$ は小さくなる。従って，(1) 式に よる地震入力エネルギーは, 弾塑性系の地震入力エネル ギーの上界を与えることになる。

Housner による (1) 式の妥当性は, 既に多くの研究 によって指摘されてお抢 ${ }^{3,107,11)}$, 更に, 加藤・秋山らは (1) 式が種々の構造特性や復元力特性の形状に依存しな いことを指摘している ${ }^{3)}$ 。従って，本論では，骨組の形 状や剛性分布, 質量分布などに拘らず, 地震大力エネル ギーを(1) 式で評価する。

仮定（ii）は，地震外乱に対する塑性变形による骨組 全体のエネルギー吸収量が，骨組各部の変形灾答の位相 差に関係なく，各部のエネルギー吸収量の単純和で与え られることに基づいており，また，塑性履歴による履歴 減衰を無視することを意味している。履歴減衰に着目し た観点からは，最適降伏震度の存在が指摘されている22，

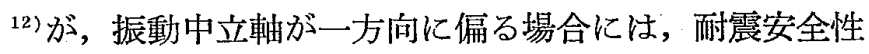
を検討する上で危険側の評価を与えることになる ${ }^{8\rangle}$ 。五 十嵐, 小川らは, 強い地震外乱に対する骨組構造物の変

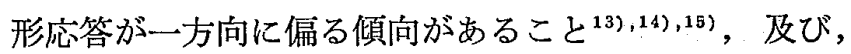
任意の変形履歴を受ける骨組の荷重変形関係が一方向荷 重変形関倸己対応ゔけられること神などから，骨組の内 部仕事を一方向荷重変形関倸兮ら評価しており ${ }^{11)}$, 本論 においても設計用地震荷重を過大評価するといら意味で 
安全側の評価を与える仮定（ii）を採用した。

地震時のエネルギーバランス関係は， $E^{e}, E^{G}$ をそれ ぞれ内部仕事及び静的鉛直倬重による仕事とすれば，次 式によって安全側に近似される ${ }^{11}$ 。

$$
E^{F}+E^{G}=E^{e}
$$

骨組全体の内部仕事 $E^{e}$ は，仮定（ii）ょり $Q_{D j}, h_{j}$, $R_{j}$ をそれぞれ $j$ 層の設計層せん断力，層高及び層閒変 形角とすれば，下式で表される。

$$
E^{e}=\sum_{j=1}^{F} \sum_{R=0}^{R_{j}} \lambda Q_{D j} h_{j} \Delta R_{j}
$$

ここで, $F$ は層数， $\lambda$ は層せん断力の大きさを表す荷重 係数である。(3) 式は最下層柱脚位置の転倒モーメント $M_{0 V T}$ 及び有效棈造回転角 $\theta_{E F^{17}}$ を用いて, 次のよう に書ける。

$$
\begin{aligned}
& E^{e}=\Sigma M_{O V T} \cdot \Delta \theta_{E F} \\
& M_{O V T}=\lambda \sum_{j=1}^{F} Q_{D j} h_{j}, \Delta \theta_{E F}=\frac{\sum_{j=1}^{F} Q_{D j} h_{j} \Delta R_{j}}{\sum_{j=1}^{F} Q_{D j} h_{j}}
\end{aligned}
$$

即ち, $E^{e}$ は $P \Delta$ 効果を無視した $M_{O V T}-\theta_{E F}$ 曲線の下 の面積で表され ${ }^{17)}$, 設計用地震荷重の大きさに依存す る。

静的鉛直荷重による仕事 $E^{G}$ は，水平変位に伴う鉛直 変位のみを考慮すれば，下式で与えられる。

$$
E^{G}=\frac{1}{2} W_{T} \sum_{j=1}^{F}\left(1-\xi_{j}\right) h_{j} R_{j}{ }^{2}
$$

ここで， $\xi_{j}$ は無次元高さであり,$W_{i}$ を $i$ 層重量とし て, 次式で表される。

$$
\xi_{j}=\frac{1}{W_{T}} \sum_{i=1}^{j-1} W_{i}
$$

(2) 式に扔ける地震入力エネルギー $E^{F}$ は，(1) 式に 示すように速度応答スペクトル $S_{V}$ に依存し， $S_{V}$ は系 の基本固有周期 $T$ の関数として表される。一方, 塑性 設計骨組構成部材の必要断面性能は, 設計用地震荷重の 関数として表される。従って, 塑性設計骨組の弾性剛性, ひいてはその基本固有周期が設計用地震荷重によって表 現でき, 結局, 地震入力エネルギーが設計用地震荷重の 関数となる。

以上に上り，(1)，(4) 及び（6）式を（2）式のエネル ギーバランス式に代入すれば設計用地震荷重を未知数と する方程式が得られる。後述するように，この方程式は 種々の設計変数を含んでおり, 設計用地震荷重にこれら の設計変数がどのような影響を及ぼすかを明らかにする ことが本論の主目的である。

\section{§3. 完全剛塑性骨組の設計用地震荷重と倒壊安全率} の関係

ここでは，はり降伏型骨組の塑性設計用地震荷重の定 性的傾向を把握することを目的とし，骨組構成部材の材
端力ー材端変形関係がすべて 完全剛塑性型である骨組を 対象に, 設計用地震荷重之倒塤安全率の関倸について考 察する。

地震時の外部仕事が骨組の静的倒壊限界までの内部仕 事より大きければ骨組は倒壊する。この倒壊に刘与る安 全率 $F_{S}$ は, Housner によって次のように定義されて (るる ${ }^{18)}$ 。

$$
\frac{W_{T}}{2 g}\left(F_{S} \cdot S_{V}\right)^{2}+E_{u}{ }^{G}=E_{u}{ }^{e}
$$

但し， $E_{u}{ }^{G}, E_{u}{ }^{e}$ はそれぞれ骨組が倒壊に致るまでの静 的鉛㨁荷重による仕事, 及び内部仕事である。（8）式は， 設計時に想定された速度スペ クトル $S_{V}$ の $F_{S}$ 倍の速度ス ペクトルを与える地震外乱に 対して，骨組が倒壊すること を意味している。 $E_{u}{ }^{G}, E_{u}{ }^{e}$ は， $R^{u}$ を静的倒壊限界点 ${ }^{15}$ に対応する骨組の変形角とす れば, 図一1 に示すはり降伏 型骨組に詨して次のように与

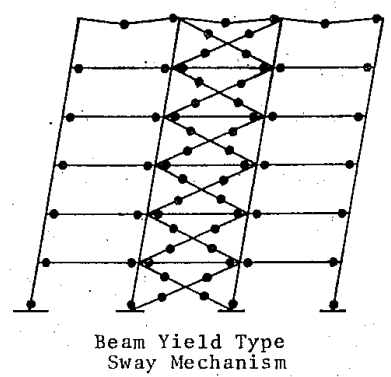

図一1 えられる。

$$
\begin{aligned}
& E_{u}{ }^{G}=\frac{W_{T}}{2}\left(R^{u}\right)^{2} \sum_{j=1}^{F}\left(1-\xi_{j}\right) h_{j} \\
& E_{u}{ }^{e}=\sum_{j=1}^{F} Q_{D j} h_{j} R^{u} \ldots \ldots \ldots \ldots \ldots \ldots \ldots \ldots
\end{aligned}
$$

上式で，設計用層せん断力 $Q_{D j}$ は， $C_{B u}$ ，終局ベース シャー係数, $C_{j}$, を終局層せ儿断力分布係数として, 次 式で表されれる。

$$
Q_{D j}=C_{B u} C_{j} W_{T}\left(1-\xi_{j}\right)
$$

上式を（10）式に代大して，㳄式を得る。

$$
E_{u}{ }^{e}=C_{B u} W_{T} R^{u} \sum_{j=1}^{F} C_{j}\left(1-\xi_{j}\right) h_{j} \cdot
$$

倒壊はエネルギー的には，「水平変位の増大に伴う静 的鉛直荷重による仕事増分が，骨組の内部仕事増分を上 回ること」と定義できる ${ }^{11}$ から，

$$
\Delta E_{u}{ }^{G}=\Delta E_{u}{ }^{e}
$$

より，静的倒壞限界点法次のように与えられる。

$$
R_{u}=\frac{C_{B u} \sum_{j=1}^{F} C_{j}\left(1-\xi_{j}\right) h_{j}}{\sum_{j=1}^{F}\left(1-\xi_{j}\right) h_{j}} .
$$

（9）（14）式の関係を（8）式に代入すれば，完全剛塑 性骨組の設計用地震荷重 $\left(C_{B u}, C_{j}\right)$ ）倒壊安全率 $F_{S}$ との関倸が次のように得られる。

$$
\frac{F_{S} S_{V}}{\sqrt{g}}=\frac{C_{B u} \sum_{j=1}^{F} C_{j}\left(1-\xi_{j}\right) h_{j}}{\sqrt{2} \sqrt{\sum_{j=1}^{F}\left(1-\xi_{j}\right) h_{j}}}
$$

ここで, 単位質量当りの地震入力エネルギーを, 骨組 の固有周期に拘らず一定, 即ち， $S_{V}$ を一定とすれば, 骨組の層数に無関係に一定の倒壞安全率を有するのに必 
要な $F$ 層骨組の終局ベースシャー係数 $C_{B u}{ }^{F}$ は, 式より次のよらに得られる。

$$
\frac{C_{B u}{ }^{F}}{C_{B u}{ }^{1}}=\frac{\sqrt{h_{1} \sum_{j=1}^{F}\left(1-\xi_{j}\right) h_{j}}}{\sum_{j=1}^{F} C_{j}\left(1-\xi_{j}\right) h_{j}}
$$

但し， $C_{B u}{ }^{1}$ は 1 層骨組の終局ベースシャー係数である。

次に,倒壞安全率の代りに, 許容限界変形角 $R^{a}$ によっ て骨組変形が制限される場合を考える。変形角が $R_{a}$ の ときの $E^{G}$ 及び $E^{e}$ は，それぞれ (9) 及び (12) 式の $R^{u}$ を $R^{a}$ に置き換えて得られる。これらを(2) 式に 代入し，層数に関係なく $R^{a}$ が同じであるとすれば， （16）式の場合と同様にして次式が得られる。

$$
\frac{C_{B u}{ }^{F}}{C_{B u}{ }^{1}}=\frac{h_{1}}{\sum_{j=1}^{F} C_{j}\left(1-\xi_{j}\right) h_{j}} \cdot \frac{S_{V^{2} / g}}{S_{V}{ }^{2} / g+\left(R^{a}\right)^{2} \sum_{j=1}^{F}\left(1-R^{a}\right)^{2} h_{1}}
$$

上式は， $R^{a} \rightarrow R^{u}$ の極限において，(16) 式と一致する。

(16) 式あるいは (17) 式より $C_{B u} F$ 学得るには，層 せん断力分布係数 $C_{j}$ が必要であり，また，骨組の崩壊 機構特性は, はり柱強度比だけでなく, 荷重分布にも依 存するから， はり降伏型骨組の塑性設計においても， $C_{j}$ を如何に設定するかが重要となる。 $C_{j}$ については，骨 組の質量, 剛性分布や地震外乱の周波数特性などにあ⿱ り影響されず，主として勒性率や累積塑性変形倍率な ど，変形态答と密接な関係にあることが指摘されてお $\eta^{199,20)}$, 筆者らは, 次式で与えられる $C_{j}$ が, 加藤・秋 山らによって得られた各層の累積塑性変形応答倍率を一 様化する最適降伏せ几断力分布係数 ${ }^{20)}$ と良く一致するこ とを示しだท。

$$
C_{j}=\frac{1}{\sqrt{1-\xi_{j}}} \cdot \sqrt{\frac{h_{1}}{h_{j}}}(j=1,2, \cdots, F) \cdots
$$

上式は, 各層の倒壞安全率一定といら条件から得られ ${ }^{18)}$, 図一2 に（18）式と文献 20）に示されている值とを比較 して示す。

（18）式を用い，各層の層高及び重量がすべて等しい場 合について (16)，(17）式を図示すれば，図一3のよう になる。図一 3 で, 横軸は骨組の層数 $F$, 縦軸は， $F$ 層 骨組の必要終局ベースシャー係数と 1 層骨組のそれとの

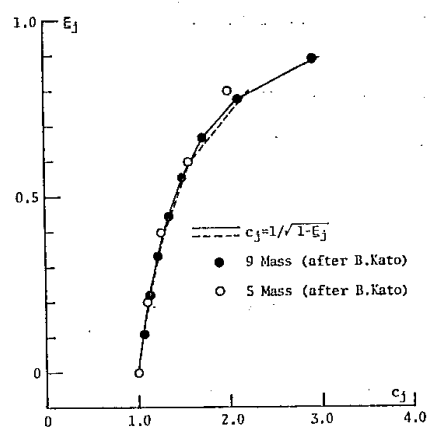

図一2

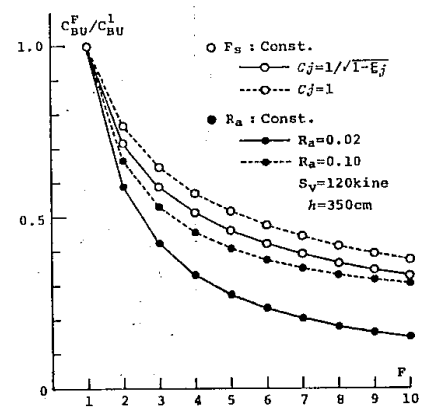

図一3
比であり，○印は (16) 式 ( $F_{S}$ 一定), 印仙 (17) 式 ( $R_{a}$ 一定) による值を表している。な挔，(17）式の計 算に当って用いた $R^{a}, S_{V}, h$ などの值は図中に示され ている。

(16) 式による結果は， $C_{j}=1$ の場合についても示さ れているが，(18) 式の $C_{j}$ の場合と大差なく, 終局べー スシャー係数 $C_{B u}$ は, 層せん断力分布係数 $C_{j}$ にあま り依存しないと言える。また，(16) 式による $C_{B u}$ の值 は，(17）式の值より大きくなっているが，これは，層 数 $F$ の増加に伴って静的倒壊限界点の变形角 $R^{u}$ ((14) 式参照) が大きくなり， $R^{a}$ が一定であれば倒壊安全率 $F_{S}$ が小さくなることによるものである。

図一3 で顕著に認好られるとは，“層数 $F$ の増加と 共に，(16)，(17）式の何れの場合も $C_{B u}$ が双曲線的に 小さくなっていることであり，これは下記の理由に基づ いている。

はり降伏型骨組の内部仕事は，(14) 式を(12) 式に代 入して下式で与えられる。

$$
E_{u} e=\frac{C_{B u^{2}} W_{T}\left[\sum_{j=1}^{F} C_{j}\left(1-\xi_{j}\right) h_{j}\right]^{2}}{\sum_{j=1}^{F}\left(1-\xi_{j}\right) h_{j}}
$$

$C_{j} \geq 1$ であるから，上式注，

$$
E_{u}{ }^{e} \geq C_{B u^{2}} W_{T} \sum_{j=1}^{F}\left(1-\xi_{j}\right) h_{j}
$$

と書ける。各層の重量及び層高がすべて等しい場合,

$$
W_{T}=F W, \xi_{j}=(j-1) / F, h_{j}=h
$$

であるから，上式は次のようになる。

$$
E^{e} \geq C_{B u^{2}} W h F(F+1) / 2
$$

従って，はり降伏型骨組の内部仕事は，層数 $F$ の増加 に伴って 2 次関数的に増大寸る。一方, 地震大力エネル ギーは, 層数即ち全質量と 1 次関係にあり, 従って, 図 -3 に示すように終局ベースシャー係数は層数の増加に 伴って小さくなる。

このように，はり降伏型骨組の終局ベースシャー係数 を評価する上で, 骨組の層数が一つの重要なファクター となる。

\section{\$4. 塑性設計骨組の弾性剛性と基本固有周期}

本節では，はり降伏型塑性設計骨組の弾性剛性及び基 本固有周期を設計用地震荷重 $\left(C_{B u} . C_{j}\right)$ の陽な関数と して表現する。対象とする骨組の形状は図一4 に示すよ らに; 層高 $h$, スパン長 $l の F$ 層 $S$ スパン均等 骨組であり，筋違は連層 X型とする。

4-1 部材断面性能 設計用地震荷重に対す る骨組構成部材の必要断 面性能は, 文献 23）の方

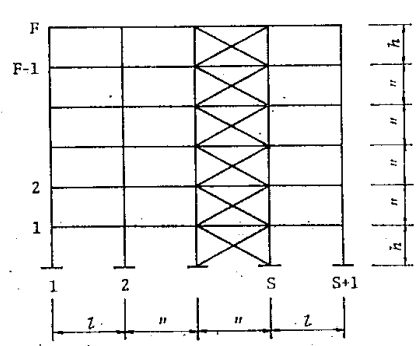

图-4 
法に基らきき，下記の諸条件に従って算定されるものとす る。

（1）はりの中間荷重は，単位長さあたりひの等分 布荷重とし，骨組総重量 $W_{T}$ を次式で与える。

$W_{T}=w F S l$

（2）層モーメントは，最下層を除いて上下層に均等 に配分する。

（3）過街重時荷重係数は考慮しない。

（4）柱，はりはそれぞれ広幅及び中細幅 $\mathrm{H}$ 形鋼強軸 廻り，笳違は広幅 $\mathrm{H}$ 形鋼弱軸廻りとし，断面性能は次式 に従って連続的に変化するものとする ${ }^{21)}$ 。

$I=\alpha_{I} Z_{p}^{4 / 3}, A=\alpha_{A} Z_{p}^{2 / 3}$

但し $I, Z_{p}, A$ は各々断面 2 次モーメント, 塑性断面 係数, 断面積である。

（5）軸力による柱の低隇塑性モーメント $M_{p c}$ を次 式で与える゙)。

$$
M_{p c}=\operatorname{Min} .\left\{M_{p}, 1.14 M_{p}(1-n)\right\}, M_{p}=\sigma_{y} Z_{p}
$$

但し, $n$ は軸力比, $\sigma_{y}$ は降伏点応力度である。

（6）崩壊機構構成時の柱モーメント分布は，節点は り端モーメント和を分割層 モーメント比に従って配分 し ${ }^{24)}$ ，はり崩壊機構を構成させるために，柱の設計式は 柱の曲げモーメント及び軸力をそれぞれ $M_{c}, N_{c}$, 柱断 面の形状係数を $f_{c}$ として次式で与える ${ }^{23)}$ 。

$$
\frac{N_{c}}{A}+\frac{f_{c} M_{c}}{Z_{p}}=\sigma_{y}
$$

(7) 崩壊機構構成時の筋違の水平力分担率 $\beta$ 法, 全 㬝に亘って一定值とする。

（8）筋違断面は下式によって算定する。

$$
\begin{array}{r}
\sigma_{y} A_{j}+N_{c}=\sqrt{1+t^{2}} \beta C_{B u} C_{j} W_{T}\left(1-\xi_{j}\right) \\
(j=1,2, \cdots, F) \cdots \cdots \cdots \cdots \cdots
\end{array}
$$

但し, $t=h / l$ は層高スパン長比, $N_{c}$ は座屈後の耐力低 下を考慮した圧縮側筋違の終局耐力21)である。

上記の諸条件により，はり中間荷重を等価な中央集中 荷重に置換し，

$$
\begin{aligned}
& \bar{M}_{j}=\frac{1}{2}(1-\beta) C_{B u} W_{T} h\left[C_{j}\left(1-\xi_{j}\right)\right. \\
& \left.+C_{j+1}\left(1-\xi_{j+1}\right)\right]
\end{aligned}
$$

とおけぼ， $j$ 層はりの必要塑性断面係数は次式で与えら れる。

$$
\left.\begin{array}{ll}
Z_{p j}=\frac{\bar{M}_{j}}{2 S \sigma_{y}} & \left(\bar{M}_{j} \geq \frac{W_{T} h}{4 F t}\right) \\
Z_{p j}=\frac{1}{4 S \sigma_{y}}\left[\bar{M}_{j}+\frac{W_{T} h}{4 F t}\right] & \left(\bar{M}_{j}<\frac{W_{T} h}{4 F t}\right)
\end{array}\right\}
$$

但し, 最下層 $(j=1)$ では, 柱脚に塑性ヒンジが形成さ れるため, 層モーメントの配分比が一般層と異なり ${ }^{23)}$,

（27）式は若干修正される。（28）式を式（23）に代大し て, はりの断面性能が設計用地地震荷重によって表現さ
れる。

同様に，(25），(26）式より柱及び管違の断面性能が地 震荷重の関数として表される。

\section{4-2 弾性剛性}

ラーメン部分の $j$ 層のせん断剛性 $G_{j}{ }^{R}$ は, 図一5に 示すように, $j$ 層で切り出した骨組系を考え,

$$
M_{j+1}=M_{j-1}=\frac{1}{2} Q_{j} h
$$

として有效剛性の概念 ${ }^{25}$ を適用すれば，次式で表され る。

$$
\begin{aligned}
G_{j}^{R} & =\frac{12 E K_{B} K_{c}}{K_{B}+2 K_{c}}(j=2,3, \cdots, F-1) \\
G_{F}{ }^{R} & =\frac{24 E K_{B} K_{c}}{2 K_{B}+3 K_{c}}, G_{1}{ }^{R}=\frac{12 E K_{c}\left(12 K_{B}+K_{c}\right)}{12 K_{B}+7 K_{c}} \\
G_{1}{ }^{R} & =\frac{3 E K_{c}\left(12 K_{B}+K_{c}\right)}{3 K_{B}+K_{c}} \quad(1 \text { 層骨組) }
\end{aligned}
$$

但し， $E$ はヤング係数， $K_{c}, K_{B}$ はそれぞれ柱及びはり の剛度和である。また，最上層 $(j=F)$ では $M_{j+1}=0$, 最下層では柱脚の節点回転角を 0 としている。

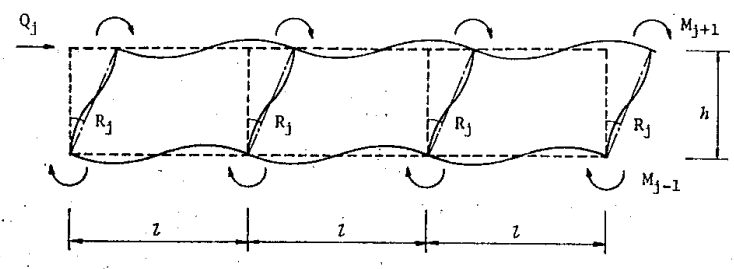

図-5

筋違のせん断岡性は，下記の仮定に基づいて誘導す る。

（i ）筋違が負担する層せん断力と層間变形角の関係 を, 引張側と压縮側の筋違を併わせて図一6 亿示寸完全 弾塑性型とする。

（ii）笳違支持柱の伸縮に伴なら骨組の歪エネルギー を無視する。

(iii) 各層の筋違は同時に降伏する。

（iv）筋違降伏時に柱，はりは弾性状態にある。

仮定 (i), (ii) は筋違付骨組の剛性を過小評価し, 従 って固有周期 $T$ を長く評価するが，設計用速度スペク トルは通常: $T$ の単調増加関数として与えられるので,

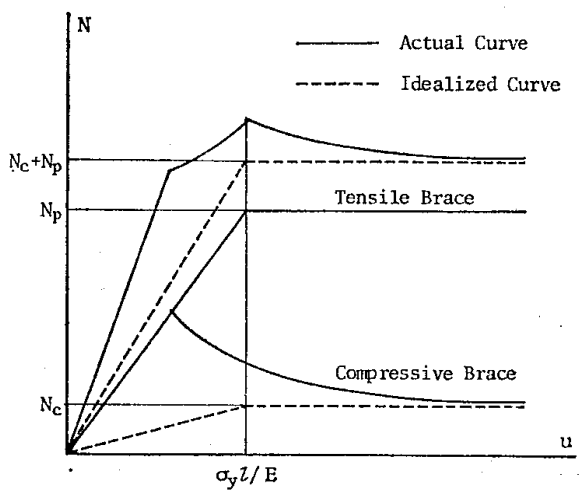

图-6 
これらの仮定は地震入力エネルギーの過大評価に㸟 着する。

上記の仮定により，j 層筋違のせ九断剛性 $G_{j}{ }^{B}$ は, 次式で与えられる。

$$
G_{j}{ }^{B}=\beta C_{B u} C_{j} W_{T}\left(1-\xi_{j}\right) h / R_{j}{ }^{e}
$$

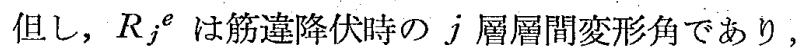

$$
R_{j}{ }^{e}=\frac{1+t^{2}}{t} \cdot \frac{\sigma_{y}}{E}+\frac{2 t}{E} \sum_{i=1}^{j-1} \frac{N_{i}}{A_{i}}
$$

となる。ここで, $A_{i}$ は $i$ 層筋違支持柱の断面積で あり， $N_{i}$ は次式で表される管違による $i$ 層の付加 軸力である。

$$
N_{i}=\beta t \sum_{j=i}^{F} Q_{D j}
$$

(29)，(30) 式より，筋違付骨組の $j$ 層の層モー メントと層閒変形角を関係づける等価せ九断剛性 $G_{j}$ は,

$$
G_{j}=G_{j}{ }^{R}+G_{j}{ }^{B}
$$

で与えられる。上式に前項 4-1 で求めた各部材断 面性能を代入すれば， $G_{j}$ が地震荷重の関数として 表される。

\section{4-3 基本固有周期}

はり降伏型塑性設計骨組の基本固有周期 $T$ は, 基本固有モードとして，設計用地震荷重に対寸る静 的弾性水平変位を用いれば， Rayleigh 法によりり次 式で表される。

$$
T=2 \pi h \sqrt{\frac{\sum_{j=1}^{F} m_{j}\left[\sum_{i=1}^{j} C_{i}\left(1-\xi_{i}\right) / G_{i}\right]^{2}}{\sum_{j=1}^{F}\left[C_{j}\left(1-\xi_{j}\right)\right]^{2} / G_{j}}} .
$$

但し， $m_{j}$ は $j$ 層質量であり， $G_{j}$ は (32) 式で与 えられる。

(33) 式から得られた基本固有周期 $T$ と層数 $F$ の 関媇を図一7 (a)〜 (f) に示す。な拉, 解析パラメー タはすべて図中に記入している。

$T$ が層数 $F$ に依存することは当然であるが，そ の他，(a)，(b) 図に示すように，終局ベースシャー 係数 $C_{B u}$ 及び筋違分担率 $\beta$ にかなり影響され， $C_{B u}$ や $\beta$ の増大に伴なって骨組の剛性が高くなり，Tは 短くなる。ラーメン部分の剛性ははり及び柱の断面 2 次モーメントに依存するから,終局強度のほぼ $4 / 3$ 乗に比例し，筋違の岡性注ほぼ終局強度に比例す る。従って，(a) 図に認められるように，Tに及ぼ す $C_{B u}$ の影響は，筋違架構に比べてラーメン架構の方 が若干顕著である。また，管違架構では，筋違支持柱の 伸縮による全体曲げ変形のため，層数 $F$ の増加に伴な っで，ラーメン架構の $T$ に接近していく傾向が認めら れる。

一方， $C_{B u}$ を一定にして骨組重量を変化させても，終 局強度は重量と比例関係にあるから，(c) 図に示すよう

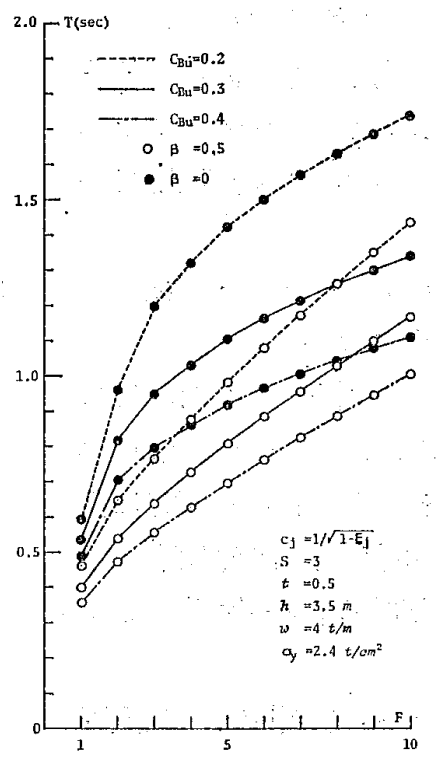

(a)

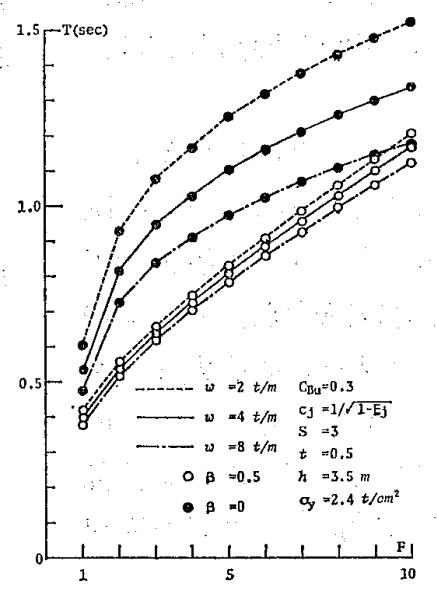

(c)

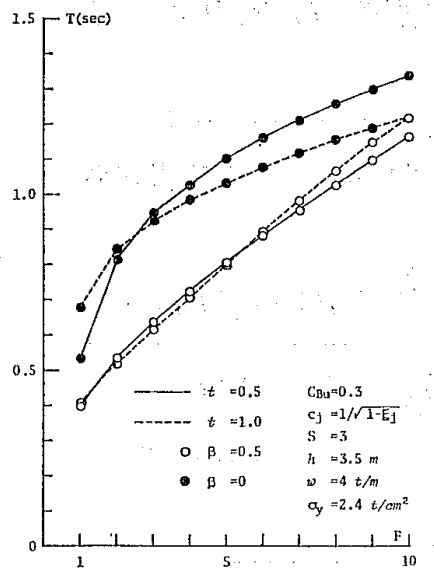

(e)

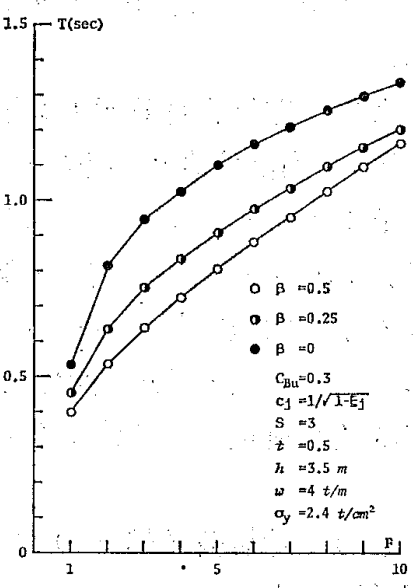

(b)

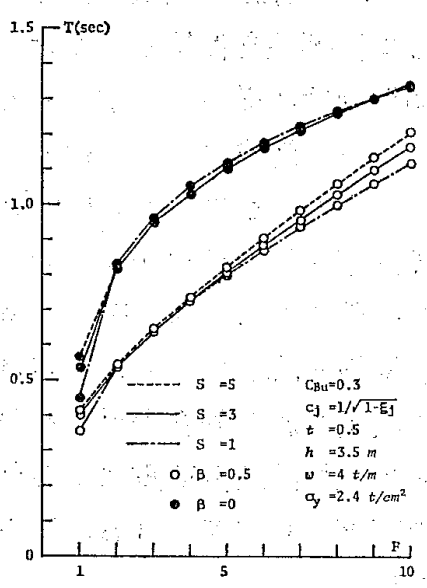

(d)

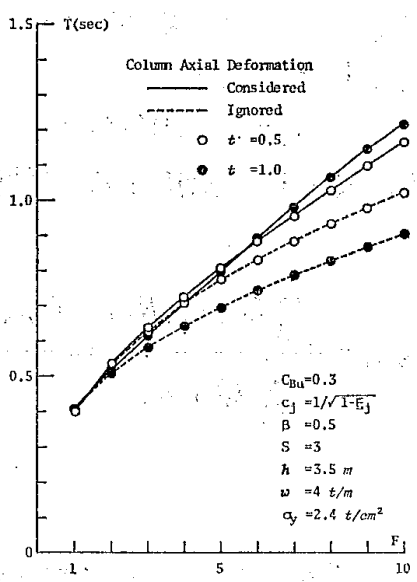

(f)
図-7

に，Tは山まり変化しない。上述したように,ラーメン の剛性は終局強度の $4 / 3$ 乗に比例するから，重量の増加 に伴なって $T$ は短かくなるが, 筋違架構では， $T$ の変 化が極めて小さい。また，(d) 及び（e）図に示すよう に, $T$ はスパン数 $S$ や層高スパン長比 $t$ の影響をあま り受けない。

（f）図は筋違架構における筋違支持柱の伸縮による全 
体曲げ変形を無視，即ち，（31）式の第 2 項を無視した 場合の解析結果を示している。 の傾角が大きいと，曲げ変形の影響はかなり顕著である が, $t=0.5$ では, 10 層骨組でもその美は 1 割程度であ る。

§5. 塑性設計骨組の必要終局ベースシャー係数

5-1 内部仕事及び静的鉛直荷重による仕事

$\$ 2$ で示したように，注り降伏型骨組全体の内部仕事 は，転倒モーメント-有効構造回転角 $\left(M_{O V T}-\theta_{E F}\right)$ 関 係の下の面積で与えられる。本論では，下記の仮定に基 ラ゙いて， $M_{O V T}-\theta_{E F}$ 関係をモデル化し，内部仕事及び 静的鉛直荷重による仕事を設計用地震荷重の関数として 表現する。

（i）骨組構成部材の材端力-材端変形関係を 完全弹 塑性型とする。

(ii）骨組が崩壞機構を構成するまでラーメン部分 は弾性岡性を保持し，また，各層の層間変形角分布は， 初期剛性に従って一定とする。

(iii）筋違については，4-2 項の仮定を適用する。

以上の仮定により, PA 効果を除いた $M_{O V T}-\theta_{E F}$ 関 係は図一8 の折線 oeca で表され， $E^{e}$ はこの折線の下 の面積である。図一8 で, $\mathrm{e}$ 点は筋違降伏点, $\mathrm{c}$ 点漰 壊機構構成点であり，a 点は構成部材の変形能力などか ら決定される許容限界変形量に対応する点とする。この とき，静的鉛直渮重による仕事 $E^{G}$ は，図一8 の斜線部 の面積として表される。以下， $E^{e}$ 及び $E^{G}$ の誘導過程 を示す。

仮定（ii）より，崩壊機構構成前の層間変形角分布 $\left\{R_{0 j}\right\}$ を(32) 式で与えられる層剛性 $G_{j}$ を用いて, 次 式で定義する。

$$
R_{0 j}=C_{B u} W_{T} C_{j}\left(1-\xi_{j}\right) h_{j} / G_{j}
$$

(5) 式より, “対応する有効構造回転角は次式で表され る。

$\theta_{E F 0}=\frac{\sum_{j=1}^{F} Q_{D} h_{j} R_{0 j}}{\sum_{j=1}^{F} Q_{D j} h_{j}}=\frac{C_{B u} W_{T} \sum_{j=1}^{F}\left[C_{j}\left(1-\xi_{j}\right) h_{j}\right]^{2} / G_{j}}{\sum_{j=1}^{F} C_{j}\left(1-\xi_{j}\right) h_{j}}$

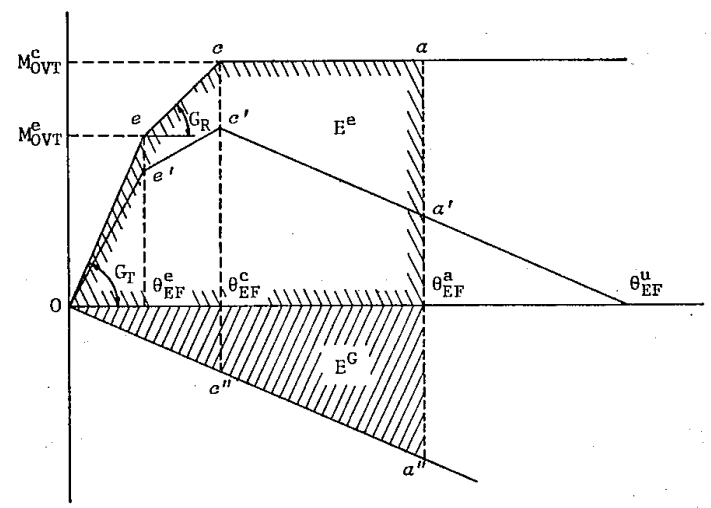

図一8
層間変形角の大きさを表すパラメータを $\theta$ とすれば, $\mathrm{c}$ 点までの変形は下式で表される。

$$
\theta_{E F}=\theta \cdot \theta_{E F_{0}},\left\{R_{j}\right\}=\theta\left\{R_{0 j}\right\}=\frac{\theta_{E F}}{\theta_{E F 0}}\left\{R_{0 j}\right\}
$$

図-8 に示す $M_{O V T}-\theta_{E F}$ 関係の初期剛性 $G_{T}$ は,

$$
M_{O V T^{c}}{ }^{c}=C_{B u} W_{T} \sum_{j=1}^{F} C_{j}\left(1-\xi_{j}\right) h_{j}
$$

であるから，(35)，(37）式より，次式で表される。

$$
G_{T}=\frac{\left[\sum_{j=1}^{F} C_{j}\left(1-\xi_{j}\right) h_{j}\right]^{2}}{\sum_{j=1}^{F}\left[C_{j}\left(1-\xi_{j}\right) h_{j}\right]^{2} / G_{j}}
$$

筋違降伏後の剛性 $G_{R}$ は，上式の $G_{j}$ を(29) 式の $G_{j}{ }^{R}$ に置き換えることによって得られる。(27)，(38) 式を用いて，筋違降伏時の $\mathrm{e}$ 点の有効構造回転角 $\theta_{E F}{ }^{e}$ 及び転倒モーメント $M_{O V T^{e}}{ }^{2}$ は，仮定（iii）よりそれぞ れ次式で与えられる。

$$
\theta_{E F}{ }^{e}=\beta M_{O V T^{c}} /\left(G_{T}-G_{R}\right), M_{O V T^{e}}=G_{T} \cdot \theta_{E F^{e}}
$$

また，崩壊機構構成点 $\mathrm{c}$ 点の有效構造回転角 $\theta_{E F}{ }^{c}$ 及び 層間変形角分布 $\left\{R_{j}^{c}\right\}$ は，それぞれ下式で与兄られる。

$$
\left.\begin{array}{l}
\theta_{E F}{ }^{c}=\theta_{E F^{e}}+\left(M_{O V T^{c}}-M_{O V T^{e}}\right) / G_{R} \\
\left\{R_{j}^{c}\right\}=\frac{\theta_{E F^{c}}}{\theta_{E F_{0}}}\left\{R_{0 j}\right\}
\end{array}\right\}
$$

はり降伏型骨組では崩壊機構構成後, 柱は基部を中心 として剛体回転し，各層同一の変形増分が生じる。従っ て，有効構造回転角 及び 層間变形角は， $\theta_{p}$ を機構構成 後の回転角増分として，それぞれ下式で表される。

$$
\theta_{E F}=\theta_{E F}{ }^{c}+\theta_{p}, \quad\left\{R_{j}\right\}=\frac{\theta_{E F}{ }^{c}}{\theta_{E F}}\left\{R_{0 j}\right\}+\theta_{p}\{1\}
$$

$\theta_{E F}>\theta_{E F}{ }^{c}$ なる変形 $\theta_{E F}$ に対する骨組全体の内部 仕事 $E^{e}$, 及び静的鉛直荷重による仕事 $E^{G}$ は, 図一8 を参照して，それぞれ次式で与えられる。

$$
\begin{array}{r}
E^{e}=\frac{1}{2} M_{O V T}{ }^{e} \theta_{E F^{e}}+\frac{1}{2}\left(M_{O V T}{ }^{e}+M_{O V T^{c}}\right) \\
\cdot\left(\theta_{E F}{ }^{c}-\theta_{E F^{e}}\right)+M_{O V T^{c}}\left(\theta_{E F}-\theta_{E F^{c}}\right) \\
\ldots \ldots \ldots \ldots \ldots \ldots \ldots \ldots \ldots \ldots \ldots \ldots \ldots \ldots \ldots \ldots \ldots \ldots \\
E^{G}=\frac{W_{T}}{2} \sum_{j=1}^{F}\left(1-\xi_{j}\right) h_{j} \\
\cdot\left[\theta_{E F}-\theta_{E F}{ }^{c}\left(1-\frac{R_{0 j}}{\theta_{E F 0}}\right)\right]^{2}
\end{array}
$$

図一8 亿招いて，折線 oe' $\mathrm{c}^{\prime} \mathrm{a}^{\prime}$ は，折線 oeca と. $E^{G}$ を与える右下りの折線 $\mathrm{oc}^{\prime \prime} \mathrm{a}^{\prime \prime}$ との代数和であり，静的鉛 直荷重の下で 比例水平荷重を受ける骨組の $M_{O V T}-\theta_{E F}$ 関係を表す。直線 $\mathrm{c}^{\prime} \mathrm{a}^{\prime}$ がいわゆる崩壊機構線であり，こ れが $\theta_{E F}$ 軸と交差する点, 即ち, 静的倒壊限界 $\theta_{E} F^{u}$ 
は，(42），43）式に（13）式を適用して，次式で与

它れる。

$$
\theta_{E F^{u}}=\frac{\sum_{j=1}^{F}\left(1-\xi_{j}\right) h_{j}\left[C_{B u} C_{j}+\theta_{E F} c\left(1-\frac{R_{0 j}}{\theta_{E F 0}}\right)\right]}{\sum_{j=1}^{F}\left(1-\xi_{j}\right) h_{j}}
$$

\$3. と同様，(44）式を（42）（43）式に代入する と, $E_{u}{ }^{e}, E_{u}{ }^{G}$ が得られる。あるいは, 許容限界変 形量が設定され，それに対応する有效構造回転角 $\theta_{E F}{ }^{a}$ が決まると， $\theta_{E F}{ }^{a}$ に対応する $E^{e}$ 及び $E^{G}$ は， それぞれ (42)，(43) 式の $\theta_{E F}$ の項に $\theta_{E F}{ }^{a}$ を代 入して得られる。

5-2 必要終局ベースシャー係数

基本固有周期の関数として速度応答スペクトルが 与完られる，(42)，(43) 式を（2）式に代入し，

（2）式を解いて必要終局ベースシャー係数 $C_{B u}$ が 得られる。本論では，以下の解析において，図一9 に示すよらな地震荷重案第 2 案 $^{26)}$ による激震の設計 用速度応答スペクトル $S_{V}$ を用いた。

はり降伏型均等骨組の必要終局ベースシャー係数 $C_{B u}$ に影響を与えるパラメータと解析に用いた值 を䋥めて列挙すれば，次の通りである。

$\begin{array}{ll}\text { O層せん断力分布係数 } & C_{j}=1 / \sqrt{1-\xi_{j}} \\ \text { ○筋違の水平力分担率 } & \beta=0,0.25,0.50 \\ \text { ○層 数 } & F=1 \sim 10 \\ \text { ○スパン数 } & S=1,3,5 \\ \text { ○層 高 } & h=3.0,3.5,4.0 \mathrm{~m} \\ \text { ○層高スパン長比 } & t=0.5,1.0 \\ \text { O骨組重量 (はり中間荷重) } & w=2,4,8 \mathrm{t} / \mathrm{m} \\ \text { O許容限界変形量 } \quad \theta_{E F}{ }^{a}=\theta_{E F} c, 0.02,0.03 \\ \text { ○降伏点応力度 }\end{array}$

許容限界変形量を支配する要因は種々考えられる が，本論では有效構造回転角 $\theta_{E F^{a}}$ として与えた。 $\theta_{E F} F^{a}$ に対応する層間変形角は (41) 式から得られ, 逆に許容限界変形量として層間変形角が与えられれば, 対応する有効構造回転角が (41) 式より得られる。

上記の解析パラメータの值に対する (2) 式の解析結果 を, 必要終局ベースシャー係数と骨組層数の関係 $\left(C_{B u}\right.$ $F$ 関係）として，図一10 (a)〜 (f) に示す。解析パラメ ータの值はすべて図中に記している。

これらの図の検討結果を縓めると，

（1）許容限界変形量が同じであれば，すべての図に 掠いて，\$3. で指摘した定性的傾问，即ち，層数 $F$ の 増加に伴なう $C_{B u}$ の減小が認められる。

(2) $C_{B u}$ に最も顕著な影響を与えるのは，(a) 図に

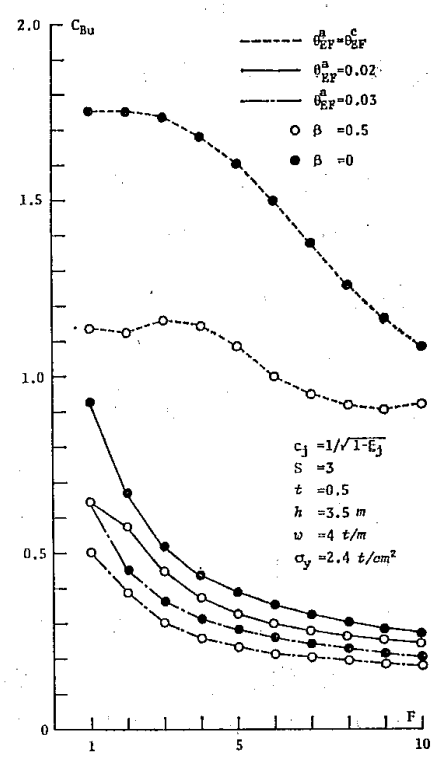

(a)

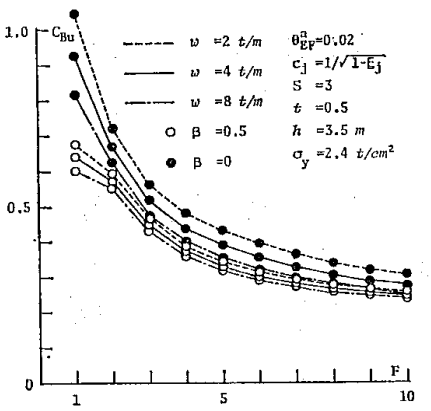

(c)

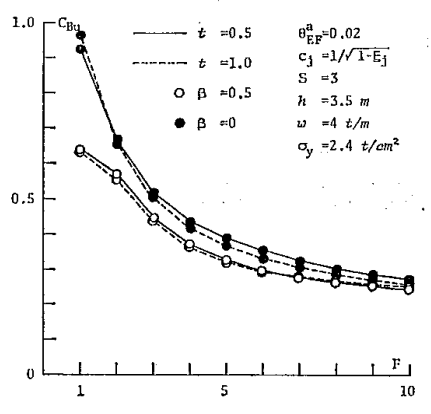

(e)

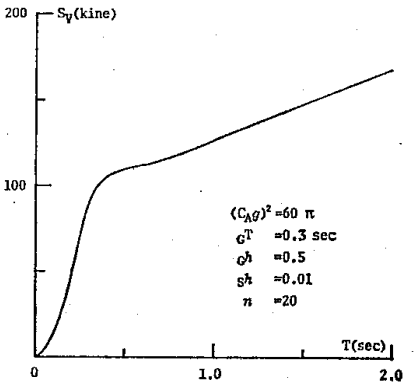

図-9

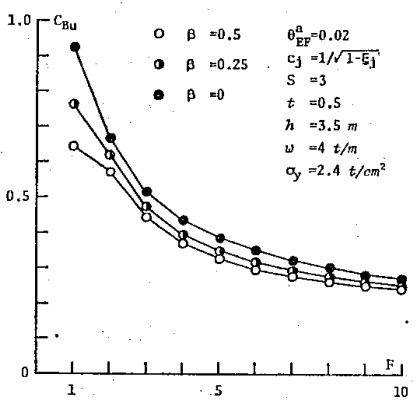

(b)

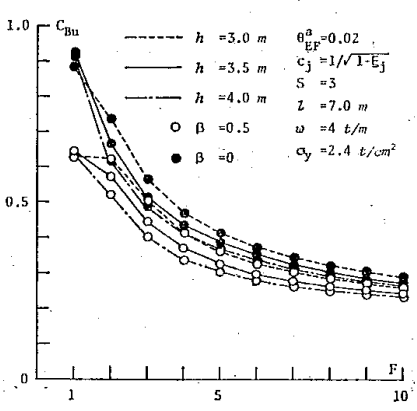

(d)

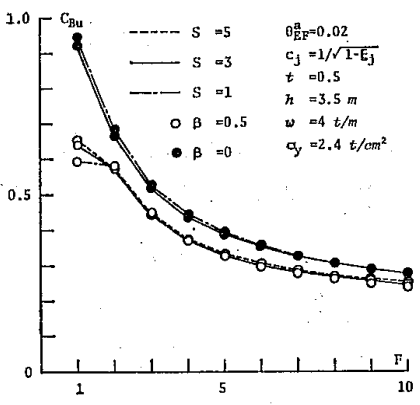

(f)
図一10

示すように，骨組の内部仕事量に直接影響を及ぼす許容 限界変形量である。特に, 激震に対して骨組に崩壊機構 を構成させないためには， $C_{B u}$ として 1 以上の值が必要 である。

(3) ラーメン架構 $(\beta=0)$ に比べて筋違架構の方が $C_{B u}$ を小さくできる。これは, 笳違架構で骨組に崩壊機 構が構成されるまでに，はり，柱より早期に降伏する筋 違によってかなりのエネルギーが吸収されること，及 び，剛性が高くなって固有周期が短かくなり，図一9に 示方設計用速度スペクトルに対しては, 地震入力エネル ギーが若干小さくなることによる。 
（4）骨組重量及び層高の増加により，(c)，(d) 図に 認められるように $C_{B u}$ は若干小さくなる。これは, む し $C_{B u}$ が一定であれば，骨組重量及び層高に比例して 部材の必要塑性モーメントが大きくなるからであるが， これらの影響は僅かである。

(5) (e)，(f) 図に示すように，スパン数 $S$ 及び層 高スパン長比 $t$ は, $C_{B u}$ にほとんど影響を与えない。 このように, $C_{B u}$ が層数以外の骨組形状に関するパラ

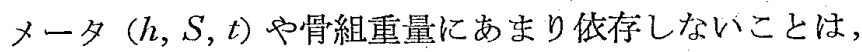
均等骨組に対して得られた本節の解析結果が，不均等骨 組に対してる適用可能であることを示唆している。

§6：弾塑性応答解析結果亡その考察

前節に扔いて，社り降伏型骨組の塑性設計用ベースシ ャ一倸数が, 種々の構造パラメータの中, 特に骨組層数 に依存することを指摘した。ここでは，骨組層数を主な パラメータとして, 塑性設計骨組の静的及び動的弹塑性 数值解析結果を示し, 前節で用いた種々の仮定事項や得 られた結諭に関する数值実験的検討を行う。

数值解析は，歪硬化係数を 0,1 次及び 2 次の減衰定 数を 0.01 とし, 文献 22) に示した方法を用いて行った。

\section{6-1 解析骨組}

骨組形状は，図-11 に示す 3 スパンの筋違付及び管 違無し均等骨組とする。解析骨組の設計用終局ベースシ ャー 係数 $C_{B u}$ の值は，下記の設計変数值を用い，前節 までに示した方法によって求めた。即ち,

$$
F=1,2,3,5,7,10, w=4 \mathrm{t} / \mathrm{m}, \theta_{E F}{ }^{a}=0.02
$$

筋違付骨組の筋違分担率 $\beta$ は全層に亘って一定とし, その值は図-12 に示寸 $\beta-F$ 関係から求めている。この 関係は,

(i) 筋違支持柱に引抜が生じないこと。

（ii）骨組全体の崩墁荷重と引張側筋違が降伏すると きの荷重との比を 1.5 程度にすること。

の 2 条件を考慮して定めたものである。

また，ここで採用した許容限界変形量の值 $\theta_{E F}{ }^{a}=$ 0.02 は, $\mathrm{H}$ 形断面はりの幅厚比が, 鋼構造塑性設計指

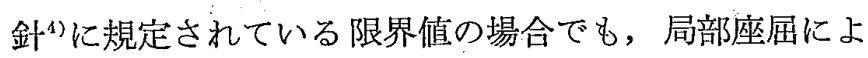
って骨組全体の耐力が低下し始まるのは， $\theta_{E F}=0.03$ 程 度であること党，及び， $\theta_{E F^{a}}{ }^{a}=0.02$ に刘する $C_{B u}$ の 值が, 現行の許容応力度設計骨組の終局耐力とほ济対応 すること年，などを侾慮して定めた。

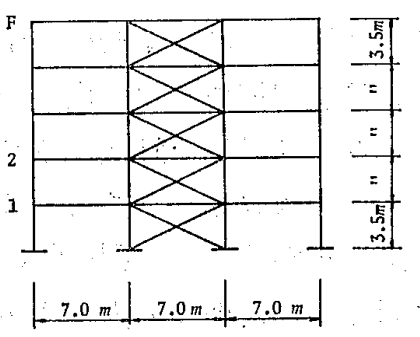

図-11

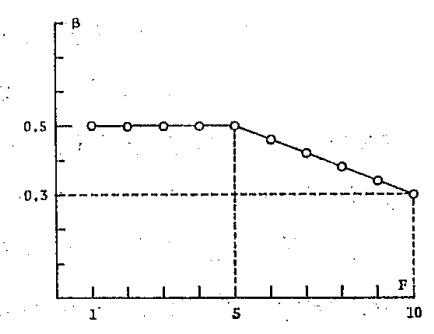

图-12

\begin{tabular}{|c|c|c|c|c|c|c|c|c|c|}
\hline & $F$ & S & $\mathrm{C}_{\mathrm{Bu}}$ & $\bar{\beta}$ & $\mathrm{s}_{\mathrm{V}}$ & $F_{S}$ & $\mathrm{~T}$ & $\mathrm{~T}_{I}$ & $\mathrm{~T}_{2}$ \\
\hline $\begin{array}{r}10 \mathrm{~B} 3 \\
7 \mathrm{~B} 3 \\
5 \mathrm{~B} 3 \\
3 \mathrm{~B} 3 \\
2 \mathrm{~B} 3 \\
1 \mathrm{~B} 3 \\
\end{array}$ & $\begin{array}{r}10 \\
7 \\
5 \\
3 \\
2 \\
1 \\
\end{array}$ & $\begin{array}{l}3 \\
3 \\
3 \\
3 \\
3 \\
3\end{array}$ & $\begin{array}{l}0.327 \\
0.447 \\
0.572 \\
0.640\end{array}$ & $\begin{array}{l}0.30 \\
0.42 \\
0.50 \\
0.50 \\
0.50 \\
0.50\end{array}$ & $\begin{array}{r}140.5 \\
127.0 \\
117.5 \\
110.0 \\
105.8 \\
87.6\end{array}$ & $\begin{array}{l}3.15 \\
3.32 \\
3.51 \\
4.00 \\
4.39 \\
4.27\end{array}$ & & & $\begin{array}{l}0.419 \\
0.304 \\
0.229 \\
0.157 \\
0.121 \\
0.090\end{array}$ \\
\hline $\begin{array}{r}10 \mathrm{~F} 3 \\
7 \mathrm{F3} \\
5 \mathrm{~F} 3 \\
3 \mathrm{~F} 3 \\
2 \mathrm{~F} 3 \\
\mathrm{LF} 3\end{array}$ & $\begin{array}{r}10 \\
7 \\
5 \\
3 \\
2 \\
1 \\
\end{array}$ & $\begin{array}{l}3 \\
3 \\
3 \\
3 \\
3 \\
3\end{array}$ & $\begin{array}{l}0.274 \\
0.326 \\
0.388 \\
0.518 \\
0.667 \\
0.924\end{array}$ & & $\begin{array}{l}144.9 \\
133.2 \\
124.1 \\
114.2 \\
109.8 \\
100.3\end{array}$ & $\begin{array}{l}3.32 \\
3.62 \\
3.93 \\
4.46 \\
4.93 \\
5.37 \\
\end{array}$ & $\begin{array}{l}1.421 \\
1.148 \\
0.936 \\
0.678 \\
0.516 \\
0.345 \\
\end{array}$ & $\begin{array}{l}1.458 \\
1.162 \\
0.940 \\
0.677 \\
0.515 \\
0.345\end{array}$ & $\begin{array}{l}0.566 \\
0.447 \\
0.355 \\
0.239 \\
0.165 \\
0.108\end{array}$ \\
\hline
\end{tabular}

解析骨組の主な構造特性を緾めて 表一1 に示寸。ここ で， $S_{V}$ は設計用速度スペクトル值， $F_{S}$ は (8) 式から 得られる倒壊安全率であり，また， $T$ は (36) 式加ら求 めた基本固有周期， $T_{1} ， T_{2}$ 流それぞれ固有值解析によ って求めた 1 次及び 2 次の固有周期でめる。筋違付骨組 では, 図一6に示すように，Tの算定に際して筋違の岡 性を低く評価しているため， $T$ は $T_{1}$ より 1 ～3 割程度 長くなってる。

6-2 静的荷重変形関係

筋違付及び筋違無し骨組の ベースシャー係数一有效構 造回転角 $\left(C_{B}-\theta_{E F}\right)$ 関係を，それぞれ図一 13,14 に示

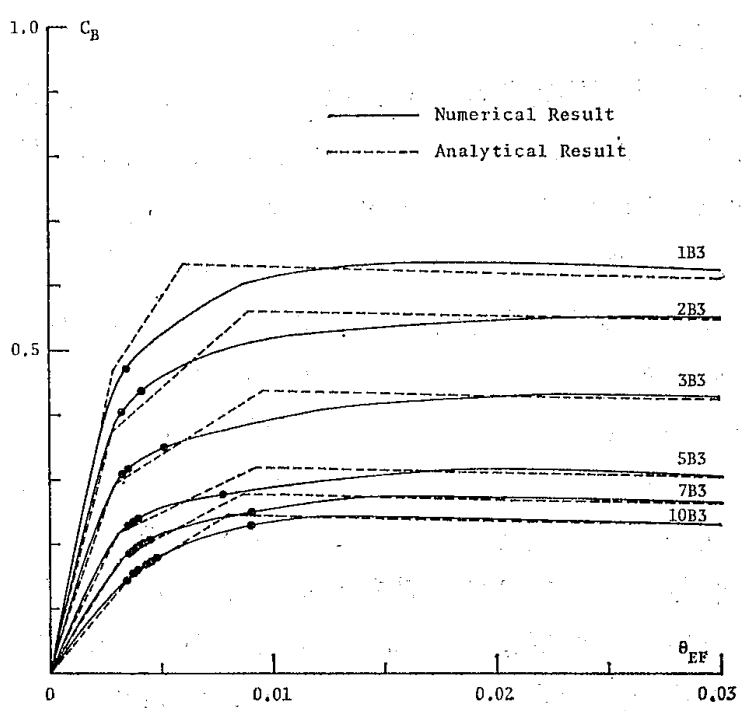

図-13

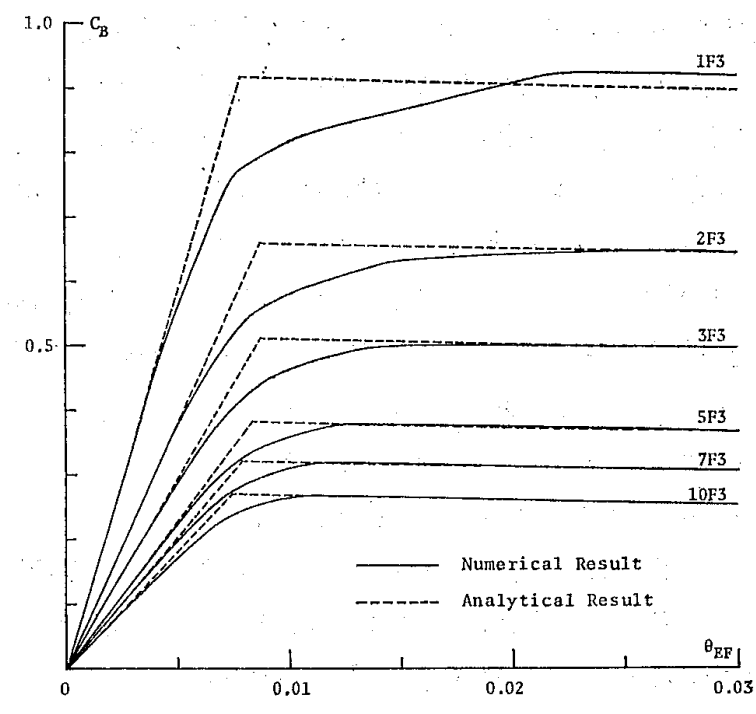

图-14 


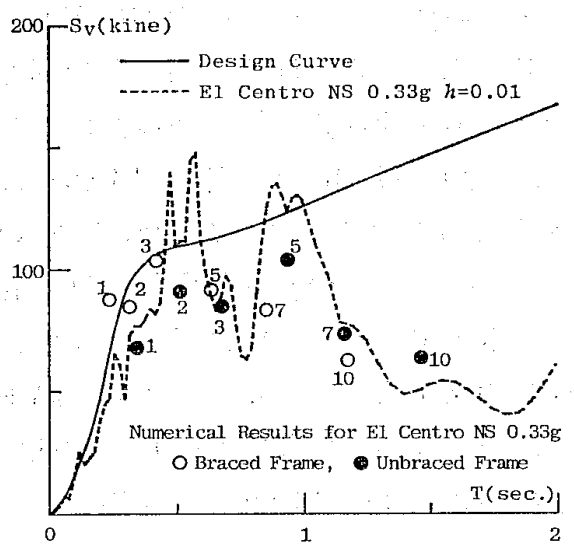

(a)

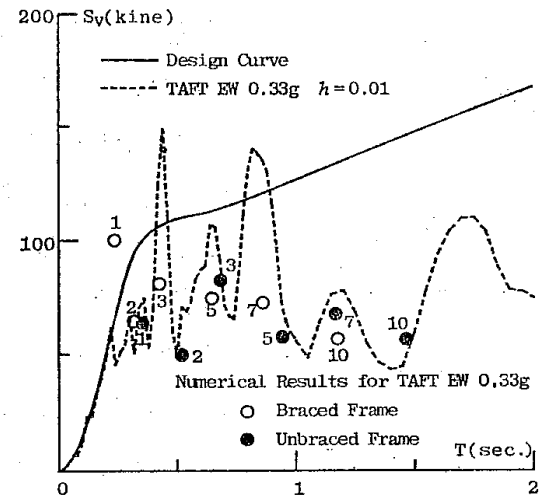

(b)

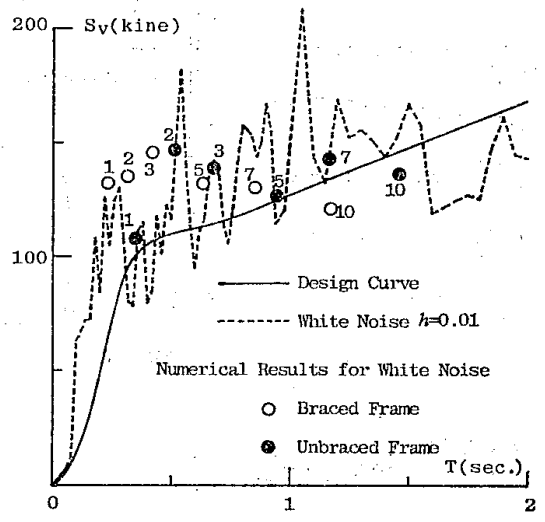

(c)

図-15

す。実線が数值計算結果, 点線は \$5. で示した解析結 果を表し，管違付骨組の $C_{B}-\theta_{E F}$. 曲線上の 印汇，引 張側筋違の降伏点を表す。解析解の弹性剛性, 崩壞機構 構成後の勾配及び崩壊荷重などは数值解とほぼ一致して 抢り，また，筋違付骨組に抒ける筋違降伏点む数值計算 結果と対応している。一方, 解析解では, 崩壊機構が構 成されるまではり，柱は弾性状態にあるとしているた め, 崩壊機構構成点近傍で数值解の耐力を過大評価する が，骨組全体の内部仕事を評価する上でこの過大評価の 影響住小さく，例えば， $\theta_{E F}=0.02$ までの内部仕事の 両者の差異は，筋違付骨組で 1 3\%，筋違無し骨組で 2〜7\% 程度である。

なお, 各骨組はすべて図一1：に示すはり降伏型崩壊機 構を構成した。

\section{6-3 動的応答解析結果どその考察}

動的応答解析の入力外乱として, 衝撃波, El Centro 1940 NS $0.33 \mathrm{~g}$ と TAFT $1952 \mathrm{EW} 0.33 \mathrm{~g}$ の初めの 7:秒，及び継続時間 10 秒の有带城ホワイトノイズ (0:1 〜 10 Hz) を用いた。衝撃波は $\delta$ 関数で表現されるもの とし，解析骨組の設計用速度スペクトル值を初速度とし て各質点に与えた。このような衝撃波を用いたのは，入 カエネルギーが解析骨組の $C_{B u}$ の決定に用いた值と厳 密に一致すること, 且つ, 衝撃応答では履歴減衰が存在 せず,変形応答の上限值が把握できると考えられること， などの理由による。衝撃波に対しては，基本固有周期の 3 倍の時刻まで解析を行った。また，有帯城ホワイトノ イズは，文献 29）の方法によって作成した 10 波の中， 図一9 に示卞設計用速度スペクトルと類似の速度スペク トルを与える1波を選んで用いた。

(I) エエネルギー応答に関して

エネルギーに関する応答結果を図一 15 19 に示す。

図一15（a）（c）注，各地震波に対する速度応答スペ クトルであり，図中の○印及び・印は，それぞれ笳違付 及び管違無し骨組に対する地震人力エネルギーを等価速

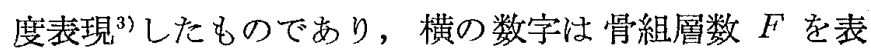
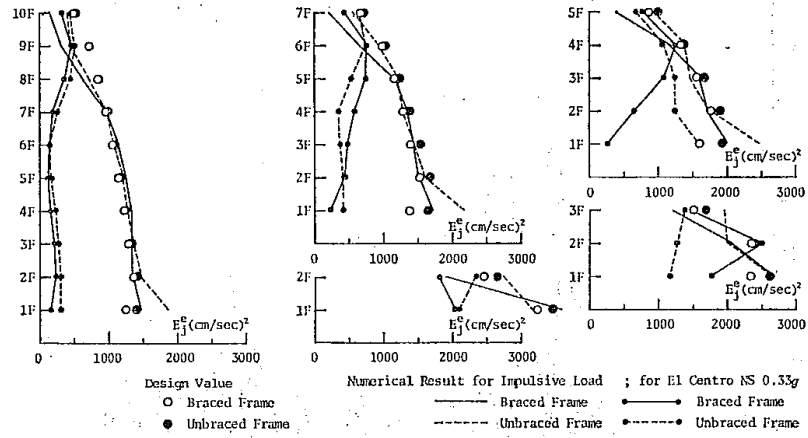

図-16

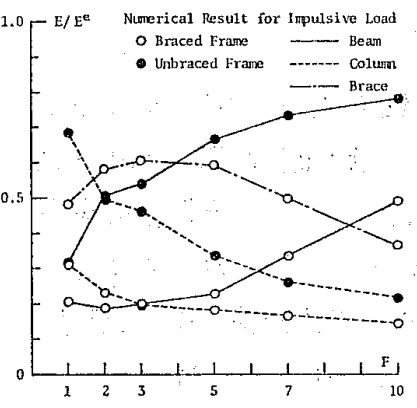

(a)

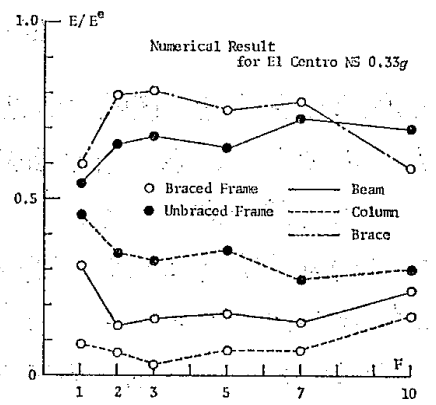

(b)
图-17

す。これらの応答值は，概して各地震波のスペクトル值 と対応して招り，本論の基本仮定が成立していると言え よう。

衝撃波及び El Centro 地震波に対する 2 層以上の骨 組の単位質量当りの内部仕事応答分布を, 縦軸に層位置 をとって図一16 に示す。衝撃波に対する応答は,設計值 (O，印) とほぼ対応している。一方；El Centro 地震 波に対しては，入力エネルギーが設計値と同程度の 5 層 以下の骨組（図一15 (a) 参照) の応答は, 設計值と類似 しているが， 7 層及び 10 層骨組では，図一15（a）ょり 明らかなよらに, 入力ェネルギーが設計值の $1 / 4 \sim 1 / 5$ 程 度であり，内部仕事応答は設計值よりかなり小さくなっ ている。

図-17 は，骨組全体の内部仕事に占める 各部材の内 

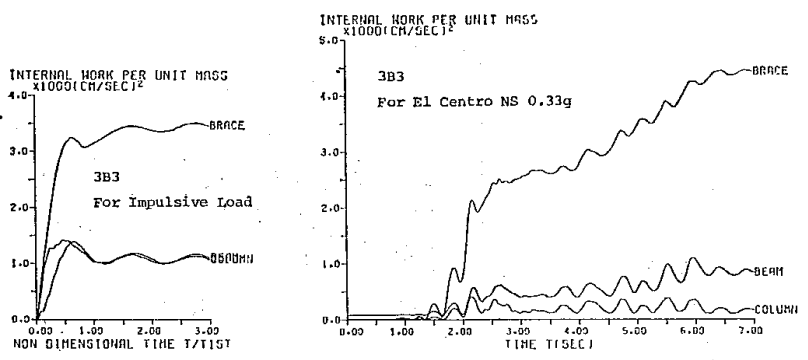

图一18

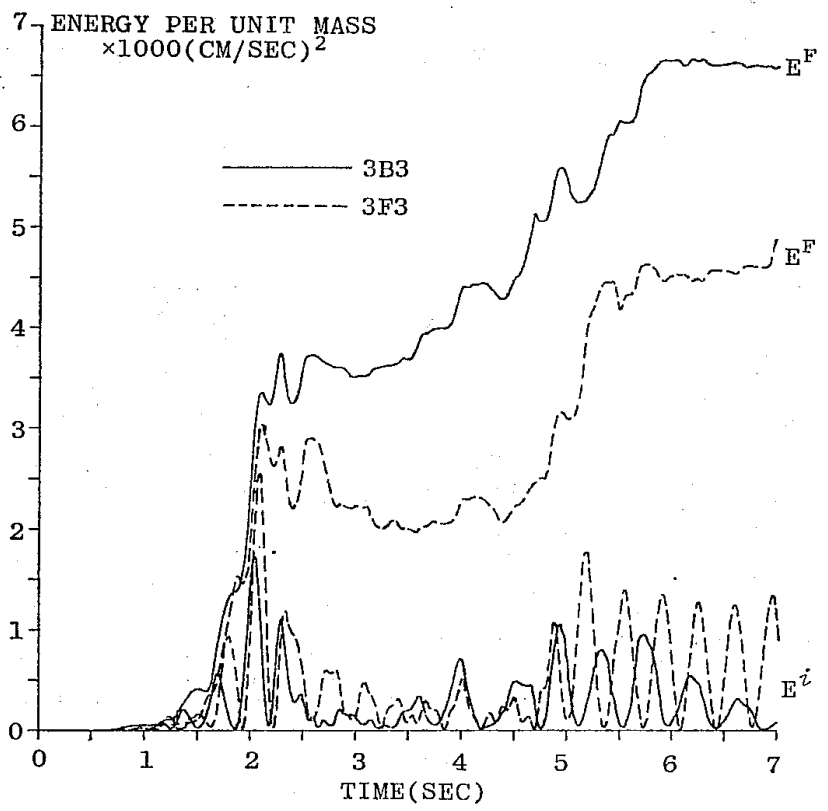

図一19

部仕事の割合を，横軸に骨組層数 $F$ をとってプロットし たものであり，(a) 図性衝撃波，(b) 図は E1 Centroに 対する応答を表す。また，一例として，3 層骨組の各部 材の内部仕事応答の時刻歷を図一18 に, 入力エネルギー $E^{F}$ 及び運動エネルギー $E^{i}$ の時刻歴を図一19 に示す。 衝撃波に対しては，風下側柱にかなりの塑性ヒンジが 生じるが，衝撃波に対する $1 ， 2$ 層骨組を除いて，はり の内部仕事は柱のそれを上迴って招り，はり降伏型塑性 設計骨組の特徴が現れている。衝撃波と El Centro 地 震波に対する内部仕事応答の差異は, 筋遥の応答に最も
顕著に現れている。衝撃波に対する筋違の内部仕事と全 内部仕事との比注, 図一12 に示筋違の耐力分担率と 同程度であるが，El Centro 地震波（他の地震波に対し てむ同様）に対しては，図一17 (b) 及び図一18 (b) に 示すように，筋違が大部分のエネルギーを吸収してい る。また, 図一19において，3 層の筋違付骨組では，筋 違無し骨組より入力エネルギーが大きいにも拘らず, 運動エネルギーの抑制効果が認められる。これらの結果 は, 繰返し力を受けた後, 極めて低荷重レベルで塑性化 する筋違が，骨組全体の履歴減衰機構として作用してい ることを示している。

(II) 変形念答に関して

多層骨組の最大変形応答を，次式で定義されるスカラ 一量で表すことを試みる。即ち，

$$
\theta_{E F}{ }^{D}=\frac{\sum_{j=1}^{F} Q_{j}^{\max } h_{j} R_{j}^{\max }}{\sum_{j=1}^{F} Q_{j}{ }^{\max } h_{j}}
$$

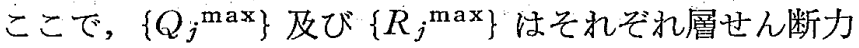
及び層間変形角の最大応答值分布である。 $\theta_{E} F^{D}$ は単に 骨組全体の最大変形の目安を与えるだけであり, 静的荷 重変形関係の表示に用いた有効構造回転角 $\theta_{E F}$ の上う なエネルギー的な意味はない。

図一20 は各地震波に対する $\theta_{E F}{ }^{D}$ を，横軸に骨組層 数 $F$ をとってプロットしたものであり，一例として，

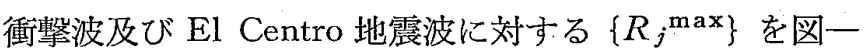
21 に，また，3 層骨組の最上層の層せん断力層間変形 角履歷曲線を図一 22 に示す。衝撃波に対する $\theta_{E F}{ }^{D}$ は, 何れの骨組においても設計值 $\theta_{E F}{ }^{a}=0.02$ とほぼ一致し ている。一方，その他の地震波に対する $\theta_{E F}{ }^{D}$ が衝撃波 の場合に比べて小さいのは，図一 22 に示すよらに，正 負両方向の塑性変形が生じている゙こと, 及び, 特に $\mathrm{El}$ Centro と TAFT 地震波に対しては，ほとんどの骨組 の入力エネルギーが設計值より小さいこと（図一15 (a)， (b) 参照) などによる。しかしながら，各骨組の終局べ 一スシャー係数 $C_{B u}$ が，表一-1 及び図一13，14 亿示す

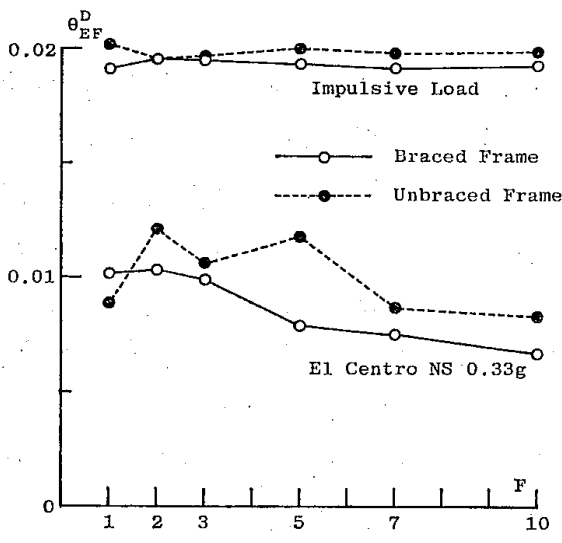

(a)

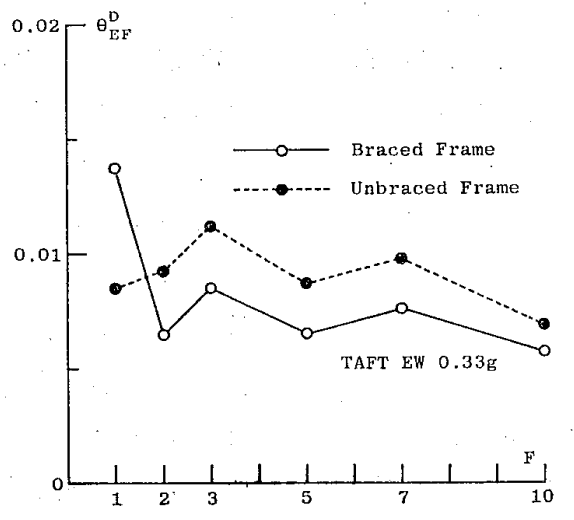

(b)

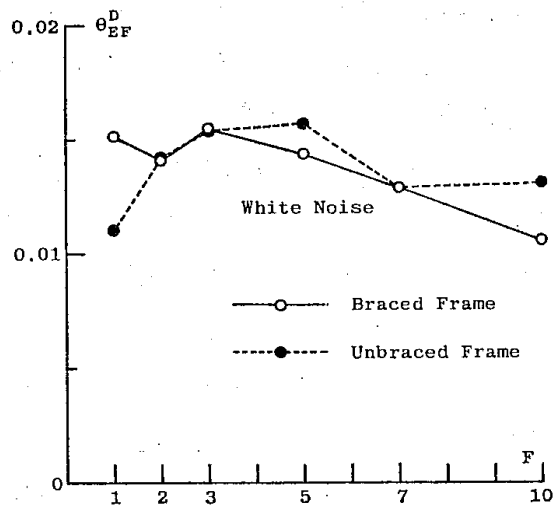

(c)

図-20. 

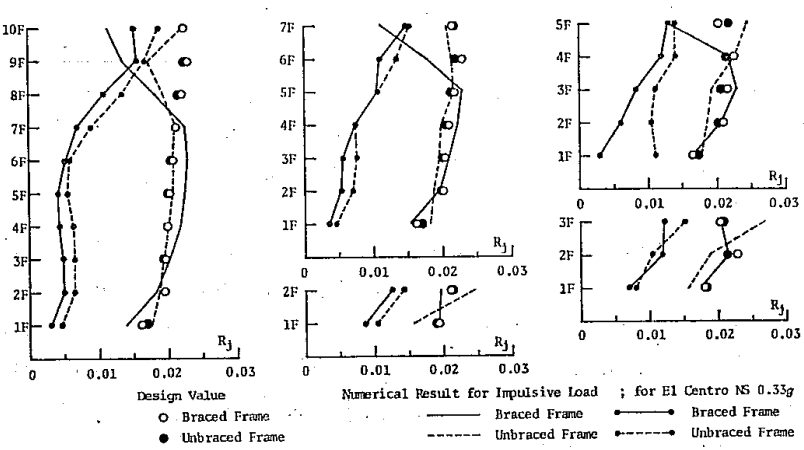

図-21
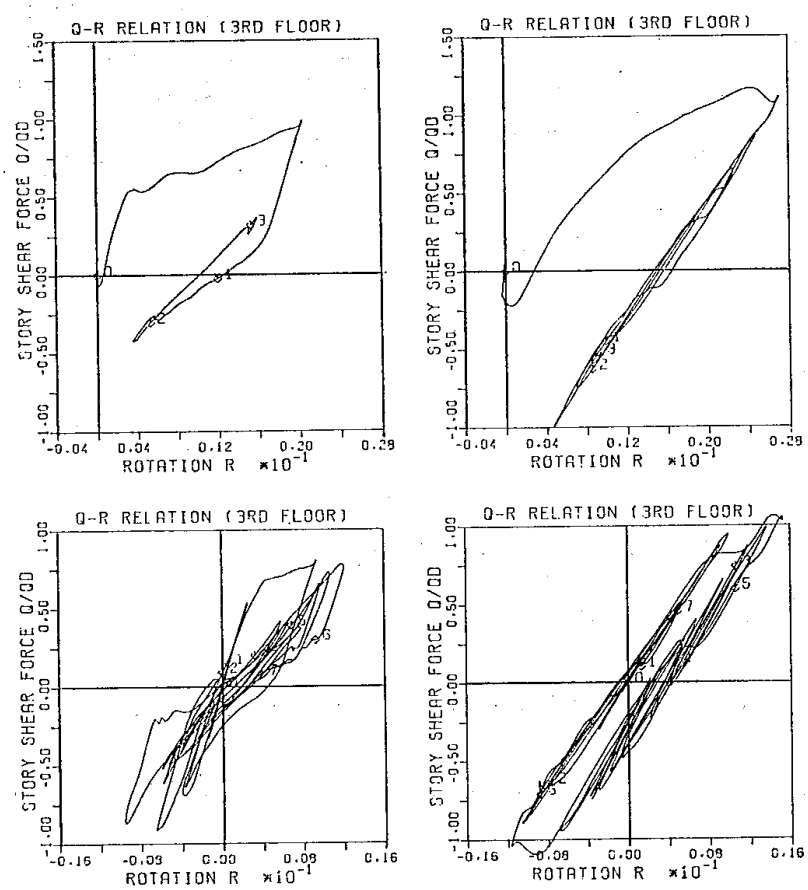

図一22

ように，骨組層数の増加に伴って急激に小さくなってい るにも拘らず，各骨組の変形応答は，同一地震波に対し ては同程度となっている。このことは，\$3. 及び $\$ 5$. で指摘したはり降伏型骨組の骨組層数と必要終局ベース シャー係数との関係を裹付けていると言えよう。また, 図一20 及び図一 21 に認められるように，筋違無し骨組 より $C_{B u}$ が小さい䇗違付骨組の方が, 若干ではあるが, 概して変形応答が小さくなっているのは, 前述した管違 の履歷減衰機構によるものと考えられる。

\section{$\S 7$. 結 論}

本論では，§2.に示した基本仮定（i）及び（ii）の下 で，はり降伏型塑性設計骨組の必要終局ベースシャー倸 数を, 地震時の外部仕事と内部仕事との近似的なエネル ギーバランス関係に基づいて検討し，次の結論を得た。

（1） はり降伏型骨組全体の内部仕事量は，層数 $F$ の 増加に伴って二次関数的に大きくなり, 許容限界変形量 あるいは倒壊安全率が $F$ に拘らず同程度であれば， $F$ の増加と共に必要終局ベースシャー係数 $C_{B u}$ は急激に 小さくなる。
（2） $C_{B u}$ の值は, 層数の他に主として骨組あるいは 骨組構成部材の許容限界変形量に依存し, 骨組重量やス パン数, 層高, 層高スパン長比などの骨組形状にはほ んど影響されない。

(3)，筋違の層せん断耐力分担率を 0.5 程度以下に抑 制することにより，筋違は $C_{B u}$ ，の值を低減させる効果 を与える。

更に，本論では衝撃波及び若干の地震波に対し，10 層 までの骨組層数及び管違の有無を主たるパラメーータとし て数值計算を行い，計算結果が上記（1）及び (3) の結 論と傾向的に一致することを確認した。一方, 結論 (2) の数值的検討については, 多量の計算量を必要とし, 本 論では未検討のまま残されている。

謝辞 本研究は, 大阪大学工学独教授・五十嵐定義博 士の御指導の下に行ったものである。末筆乍ら付記し， 感謝の意を表します。また, 本論文の数值計算は, 昭和 54 年度文部省科学研究費 (奨励研究 A) によって行っ たものである。

\section{参 考 献}

1) A.S. Veletsos and N.M. Newmark : Effect of Inelastic Behavior on the Resistance of Simple Systems to Earthquake Motions, Proc., 2nd WCEE, 1960, pp. 895-910.

2) J. Penzien : Elasto-Plastic Response of Idealized MultiStory Structures Subjected to a Strong Earthquake, Proc., 2nd WCEE, 1960.

3）加藤 勉, 秋山 宏 : 強震による構造物へのエネルギー 入力と構造物の損傷, 建築学会論文報告集, 第 235 号, 昭和 50 年 9 月, pp. 9-18.

4) 日本建築学会 : 鋼構造塑性設計指針, 昭和 50 年 11 月.

5）棚橋 諒：地震の破壊力と建築物の耐震力に関する私見, 建築雑誌, 昭和 10 年 5 月, pp. 578-587.

6) G.W: Housner : Limit Design of Structure to Resist Earthquake, Proc.; 1st WCEE, 1956.

7) G.W. Housner : Behavior of Structure During Earthquakes, Proc., ASCE, No. EM 4, Oct. 1959, pp. 109129.

8) P.C. Jennings : Equivalent Viscous Damping for Yielding Structures, Proc., ASCE, No. EM 1, Feb. 1968, pp. 103-116.

9) D.E. Hudson : Response Spectrum Techniques in Engineering Seismology, Proc., 1st WCEE, 1956.

10) G.V. Berg : Energy Consumption by Structures in Strong Motion Earthquakes, Proc., 2nd WCEE, 1960.

11）五十嵐定義, 小川厚治：鋼棈造骨組の耐震設計用動力学 モデルに関す方研究 その 4. エネルギー吸収要素の適 正鋼材量について, 建築学会論文報告集, 第 284 号, 昭 和 54 年 10 月, pp. 61-68.

12）田治見 宏 : 建築振動学, コロナ社, pp. 132-152.

13）加藤 勉, 秋山 宏, 鈴木弘之, 墚沢義和 : 鋼構造模型 の動的崩壊実験, 建築学会論文報告集, 第 241 号, 昭和 51 年 3 月, pp. 101-109.

14）藤本盛久, 緑川光正 : 正弦波入力を受ける H 形鋼柱の弾 塑性応答解析, 建築学会大会学術講演梗概集, 昭和 51 年 10 月, pp. 1097-1098.

15）石田修三：弾塑性骨組の静的及び動的大たわみ解析法, 京都大学学位論文, 昭和 50 年 6 月。

16) B. Kato and H. Akiyama : Theoretical Prediction of 
the Load Deflection Relationship of Steel Members and Frames, IABSE Symp. on Resistance and Ultimate Deformability of Structures Acted on by Well Defined Loads, 1973.

17) R. Tanabashi, T. Nakamura and S. Ishida : Overall Force-Displacement Characteristics of Multi-story Frames, Proc., of Symp. on Ultimate Strength of Structures and Structural Elements, 1969, 12, pp. 87-100.

18) G.W. Housner : The Plastic Failure of Frames During Earthquake, Proc., 2nd WCEE, 1960.

19）南井良一郎 : 震度とせん断力係数, 建築雑誌, 昭和 45 年 6 月, pp. 457-461.

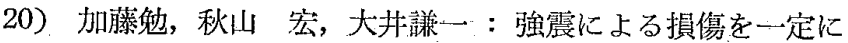
する最適降伏せん断力係数分布について一中低層鋼棈造 骨組を刘象しして一，建築学会大会学術請演梗概集，昭 和. 51 年 10 月, pp. 647-648.

21）五十風定義，井上一朗，小川厚治：龬棈造筋違付多層骨 組の塑性設計に関寸る研究（その1），建築学会論文報告 集，第 263 号，昭和 53 年 1 月, pp. 43-49.

22）井上一朗, 小川厚治：同上（その 2 ），建築学会論文報告
集，第 268 号，昭和 53 年 6 月, pp. 87-98.

23）井上一朗, 永田匡公: 同上 (その 4), 建築学会諭文報告 集, 第 283 号, 昭和 54 年 9 月, - pp. 49-57.

24）坂本 順, 小浜考朗 : 鎙構造架構の塑性設計法に関する 考察, 建築学会論文報告集, 第 203 号, 昭和 48 年 1 月, pp. $37-45$.

25) K. Heki and T. Saka.: Stress Analysis of Lattice Plate As Anisotropic Continum Plate, Proc,, 1971 IASS Pacific Symp. Part II on TENSION STRUCTURES and SPACE FRAMES, 1972, pp. 675-690.

26). 日本建築学会：地震荷重と建築構造の耐震性，I編 3 章, 1976, pp. 23-54.

27）五十嵐定義, 井上一朗, 永田匡宏：中低層銅骨組構造物 の侍重係数と崩買機構に関する将察 (その2), 建築学会 大会学術講演梗概集, 昭和 53 年 9 月, pp. 1377-1378.

28）五十嵐定義, 井上一朗, 永田匡宏：錄棈造骨組の塑性設 計用地震渮重に関する研究（その 1 ）, 建築学会近畿支部 研究報告集, 昭和 54 年 6 月, pp. 309-312.

29）星谷 勝 : 確率論手法による振動解析, 笓島出版会, pp. $46-58$.

\section{S Y NOPSIS}

UDC : $624.02: 550.34 .042$

\section{A CONSIDERATION ON THE SEISIMIC LOAD FOR PLASTIC DESIGN OF STEEL FRAMES}

\section{by KAZUO INOUE and MASAHIRO NAGATA, Members of A.I.J.}

Energy balance equation during catastrophic earthquake can be written as follows based on the energy concept introduced by G.W. Housner, that is,

where $\begin{aligned} & \frac{1}{2} M_{T} S_{V}{ }^{2}+E^{G}=E^{e} \\ M_{T} & : \text { Total mass of frame } \\ S_{V} & : \text { Pseudo velocity response spectrum } \\ E^{G} & : \text { Work done by gxavity load during earthquake } \\ E^{e} & : \text { Internal work of overall frame }\end{aligned}$

Each term of this equation can be expressed as a function of required seismic load under the assumption that the plastic drift occurs only in one direction. Therefore, seismic design load represented by the ultimate base shear coefficient and the shear force distribution coefficient is obtained analyticaly from energy balance equation.

This paper mainly deals with the ultimate base shear coefficient $\left(C_{B u}\right)$ required for the frames which result in the beam and brace yield type sway collapse mechanism. The significant aspects of analytical results are summarized in the following :

1. Internal work of overall frame is in proportion to the square of the number of story. Consequently, as the number of story increases, required value of $C_{B u}$ falls hyperbolically.

2. $C_{B u}$ is affected directly by the plastic deformability of frame, while it is hardly affected by the weight and the shape of frames except for the the number of story.

3. $C_{B u}$ of braced frames is smaller than that of unbraced frames about $10-20 \%$. 